\title{
小坂鉱業所の亜鉛製鍊
}

\section{Electrolytic Zinc Plant at Kosaka Mine}

正会員 真 栄 城 勇*

Isamu MAESHIRO

\section{1. 緒 ‥ 言}

昭和 27 年11月に操業を開始した銅・亜鉛精鉱の硫酸化 焙燒は, 第 2 次大戦後紹介された流動焙焼炉を適用して, 黒鉱中の銅，亜鉛を同時に硫酸塩とし，電解採取によつ て電気銅，電気覀鉛とする方法で当時としては画期的な 製錬法であつた。

以来10有余年, 各工程の改善と相まつて, 安定した操 業を行なつてきたが，昭和36年花岡堂屋敷選鉱場におけ る温水浮選法の採用などの選鉱技術の著しい進歩によつ て，從来分離不能とされた黒鉱中の銅・亜鉛分離が可能 となつてくるにおよび，硫酸化焙焼法もその役目を充分 に果したと考えられ, 昭和 41 年 5 月に操業を一部休止し, 6,7 月に改造工事を行ない，亜鉛精鉱の硫化焙焼法に転 換した。

硫酸化焙焼については, すでに各種の文献に発表され ているのでここでは現在の操業について記す。

現在の生産能力は, 電気亜鉛 $1,500 t$ /月で, 亜鉛製錬 の従業員は88名である。第 1 表に, 各工程別人員配置を 示す。

第 1 表 各工程人員配置表

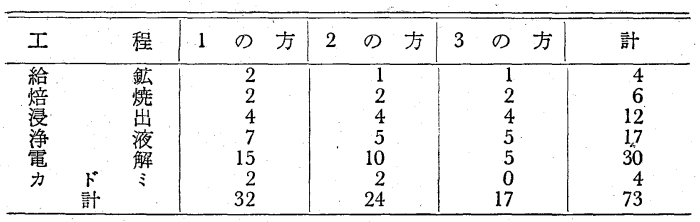

2. 操業成績（昭和42年10月現在）

1）操業系統図を第1図に示す。

2）処理元鉱 (第 2 表参照)。

処理元鉱は, すべて黒鉱鉣床から産出する亜鉊精鉱で ある。

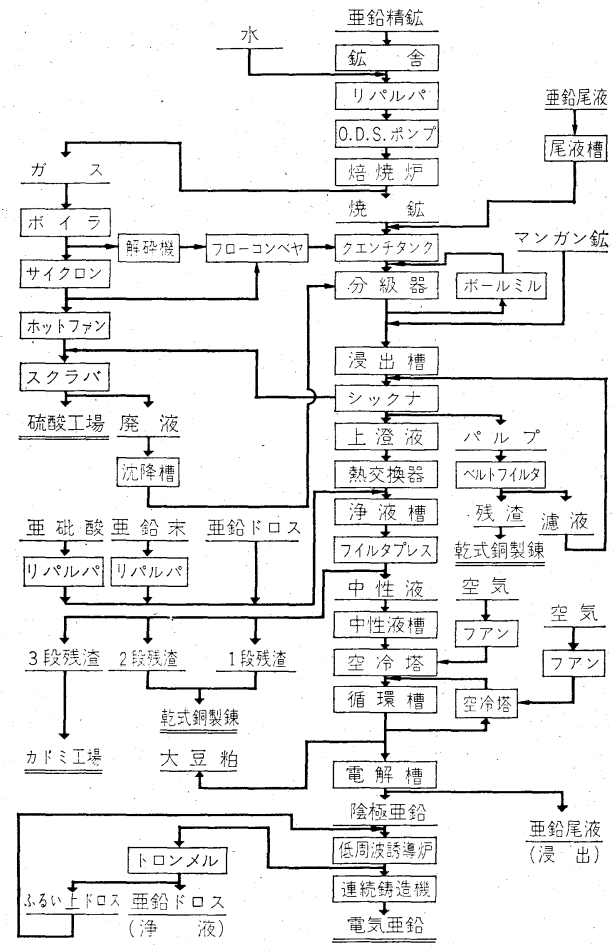

第1図操業系統図

3）生産量 (第 3,4 表参照)。

第 3 表 製品量と品位 $(\%)$

\begin{tabular}{|c|c|c|c|c|c|c|c|}
\hline 別 & 量 $(t)$ & $\mathrm{Zn}$ & $\mathrm{Cd}$ & $\mathrm{Fe}$ & $\mathrm{Pb}$ & $\mathrm{Sn}$ & $\mathrm{Cu}$ \\
\hline 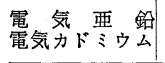 & $\begin{array}{r}1,500 \\
5\end{array}$ & $\begin{array}{l}99.998 \\
0.0006\end{array}$ & $\begin{array}{l}0.0001 \\
99.995\end{array}$ & $\begin{array}{l}0.0003 \\
0.0002\end{array}$ & $\begin{array}{l}0.0015 \\
0.0030\end{array}$ & $\left|\begin{array}{c}0.0001 \\
-\end{array}\right|$ & $0 . \overline{0}$ \\
\hline
\end{tabular}

第 4 表 副産品量と品位(\%)

\begin{tabular}{|c|c|c|c|c|c|c|c|c|}
\hline 種 & 別. & 量 $(t)$ & $\mathrm{Au}$ & $\mathrm{Ag}$ & $\mathrm{Cu}$ & $\mathrm{Pb}$ & $\mathrm{Zn}$ & $\mathrm{Fe}$ \\
\hline 浸 出液 & 残 渣 & $\begin{array}{r}580 \\
58\end{array}$ & $\begin{array}{r}\mathrm{g} / \mathrm{t} \\
8.42 \\
-\end{array}$ & $\begin{array}{r}\mathrm{g} / \mathrm{t} \\
769.8 \\
-\end{array}$ & $\begin{array}{r}3.00 \\
60.02 \\
\end{array}$ & 7.80 & $\begin{array}{r}17.00 \\
9.70\end{array}$ & $\begin{array}{r}29.00 \\
0.30\end{array}$ \\
\hline
\end{tabular}

第 2 表 亜鉛精鉱品位

\begin{tabular}{|c|c|c|c|c|c|c|c|c|c|c|c|c|}
\hline & 量 & $\mathrm{Au}$ & $\mathrm{Ag}$ & $\mathrm{Cu}$ & $\mathrm{Pb}$ & $\mathrm{Zn}$ & $\mathrm{Fe}$ & $\mathrm{S}$ & $\mathrm{Cd}$ & $\mathrm{Ni}$ & Co & As \\
\hline 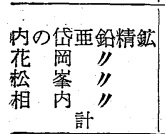 & $\begin{array}{r}\mathrm{t} \\
1,892 \\
334 \\
251 \\
393 \\
2,870\end{array}$ & $\begin{array}{c}\mathrm{g} / \mathrm{t} \\
1.5 \\
0.81 \\
0.62 \\
4.50 \\
1.75\end{array}$ & $\begin{array}{r}\mathrm{g} / \mathrm{t} \\
150.0 \\
164.7 \\
92.5 \\
250.0 \\
160.4\end{array}$ & \begin{tabular}{r|}
$\%$ \\
1.50 \\
3.30 \\
2.25 \\
2.50 \\
1.91
\end{tabular} & \begin{tabular}{r|}
$\%$ \\
1.20 \\
2.50 \\
1.54 \\
2.50 \\
1.56
\end{tabular} & \begin{tabular}{|r|}
55.00 \\
56.00 \\
57.50 \\
50.00 \\
55.68
\end{tabular} & \begin{tabular}{r|}
$\%$ \\
5.80 \\
3.80 \\
4.20 \\
9.00 \\
5.87
\end{tabular} & \begin{tabular}{r|}
$\%$ \\
34.00 \\
31.80 \\
33.20 \\
34.30 \\
33.72
\end{tabular} & \begin{tabular}{r|}
$\%$ \\
0.27 \\
0.18 \\
0.16 \\
0.33 \\
0.26
\end{tabular} & $\left|\begin{array}{l|}\% \\
0.002 \\
0.002 \\
0.002 \\
0.003 \\
0.002\end{array}\right|$ & \begin{tabular}{|l|}
$\%$ \\
0.001 \\
0.001 \\
0.002 \\
0.001 \\
0.001
\end{tabular} & $\begin{array}{l}\% \\
0.086 \\
0.174 \\
0.012 \\
0.043 \\
0.084\end{array}$ \\
\hline
\end{tabular}

* 同和鉱業株式会社小坂釷業所製鍊部長

4）主要設備 第 5 表に示す。

\section{3. 最近の技術および設 備の進歩}

昭和 41 年 8 月亜鉊製錬への転換に伴 う改造工事に採用した各工程の特徵に 
第 5 表 主要設備

\begin{tabular}{|c|c|c|}
\hline 名 & 数量 & 様 \\
\hline 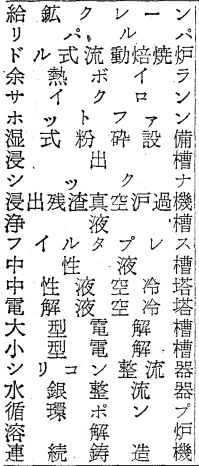 & \begin{tabular}{r|r}
1 \\
4 \\
1 \\
1 \\
3 \\
1 \\
1 \\
1 \\
6 \\
4 \\
1 \\
7 \\
9 \\
3 \\
1 \\
1 \\
78 \\
78 \\
7 \\
1 \\
1 \\
4 \\
2 \\
1
\end{tabular} & 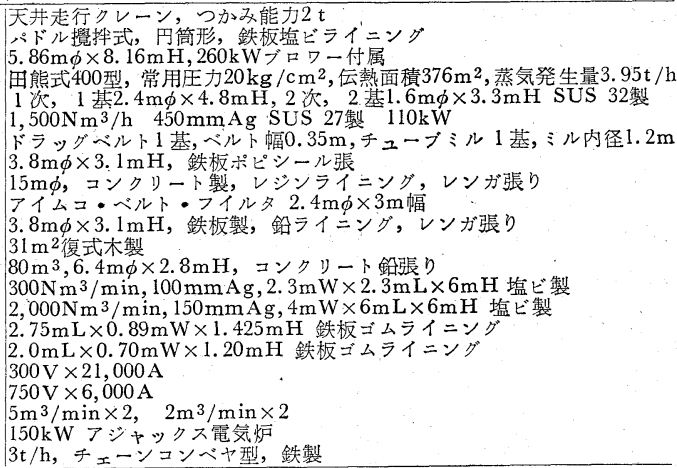 \\
\hline
\end{tabular}

の長期連続運転（昭和 41 年 8 月から 昭和 42 年 10 月現在休転なし）に成功 した。なお，焙燒炉一ボイラ間のダ クトはガスの流れを考慮して設計し たので，ベコの付着が極めて少なく 長期間の連続使用によつて, 通風抵 抗が増加することはない。また，予 備ダクトの交換は, 約10分間ででき るようになつている。

第 2 図に焙焼炉およびボイラの側 面図を示す。煤吹によって落下する 塊状焼鉱は, ボイラ出口に設置した クラッシャにより破研し，焼鉱コン ベヤで起こりがちなトラブルを防止 している。

\section{$3 \cdot 1$ 給鉱, 焙焼}

a 給釷 一従来のコンテナ輸送をダンプトラック輸 送に改めた。貯鉱能力は約 $1,500 \mathrm{t}$ で調合に応じて天井 走行クレーンのグラブバケットでつかみ, ベルト・フィ ダーにのせ，ベルト・コンベヤでリパルパに投入し，パ ルプ濃度 $78 \%$ のパルプにしてO・D・S ポンプで 3 個所か ら炉内に装入する。

第 6 表に各精鉱粒度分布を示す。

第 6 表 精鉱粒度分布

\begin{tabular}{|c|c|c|c|c|c|c|}
\hline 鉱種 粒度 (mesh) & +100 & +150 & +200 & +270 & +400 & -400 \\
\hline 内の岱重鉛精鉱 & . & 0.4 & 2.7 & 6.0 & 17.7 & 73.2 \\
\hline 花 媯 II & - & 4.3 & 13.9 & 15.1 & 6.2 & 60.5 \\
\hline 松 萃 & 0.4 & 4.0 & 11. 1 & 15.4 & 10.7 & 58.4 \\
\hline 相 央 & 0.1 & 0.5 & 0.9 & 8.8 & 9.3 & 80.4 \\
\hline
\end{tabular}

b. 焙焼炉流動焙焼炉は改造に当つて炉高を $3 \mathrm{~m}$ 高くし，キャリオーバの反応時間を長くし，炉床能率の 増大を沙っている。トワイヤーはカサ付頭で, 孔数 6 個, 孔径 $4.6 \mathrm{~mm} \phi$ のものを392本とりつけている。炉内 へのパルプ給鉱装置は当所独自のもので銅，鉛の高い黒 鉱出の亜鉛精鉱でも安定した焙焼を行なうことができ る。第 7 表滰焼条件を示す。

第 7 表 焙烧条件

\begin{tabular}{|c|c|c|}
\hline 項 & 単 & 数 \\
\hline 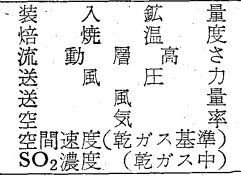 & $\begin{array}{c}\mathrm{t} / \mathrm{A} \\
{ }^{\circ} \mathrm{C} \\
\mathrm{mm} \\
\mathrm{mmAg} \mathrm{Nm}^{3} / \mathrm{h} \\
\% \\
\mathrm{~m} / \mathrm{sec} \\
\% \\
\end{array}$ & $\begin{array}{r}2,870 \\
920 \\
1,200 \\
2,600 \\
8,200 \\
120 \\
0.335 \\
11.8 \\
\end{array}$ \\
\hline
\end{tabular}

c.ボイラ 余熱ボイラには, 亜鉊鉱用廃熱ボイラ としては初めての試みである全自動煤吹機 (空気圧 $15 \mathrm{~kg}$ $\left./ \mathrm{cm}^{2}\right) 7$ 基を備えており，ボイラ内に付着したダストを 連続的に除去しているので, 休缶掃除や，予備ボイラ設 置の必要が全くなく, 炉関係の改良と相まつて, 焙焼炉
サイクロンの收じん効率は 1 次，2 次合せて $99.5 \%$ 以 上で，ホットファンのロータに付着するダスト量は極め て少なく, 年 2 回, 4 時間/回である。ホットファンのガ 不吸引量は処理鉱量に応じて, 流体継手の遠隔操作によ りコントロールしている。第 8 .表に各焼鉱分布率と粒度 を示す。

第 8 表 焼鉱分布率と粒度

\begin{tabular}{|c|c|c|c|c|c|c|c|c|c|}
\hline & 分布率 & $\begin{array}{r}\text { mesh } \\
+35\end{array}$ & +60 & +100 & $\mid+150$ & +200 & +250 & +325 & -32 \\
\hline & $53 \%$ & 6.9 & 7.8 & 12.7 & $\mid 21.8$ & $|29.7|$ & 17.5 & 2.8 & 0.8 \\
\hline & $8 \%$ & 0 & 0 & 0 & 0 & 0.3 & 16.4 & 31.3 & 52.0 \\
\hline 焼号鉱 & $39 \%$ & 0 & 0 & 0 & 0 & 0.2 & 8.3 & 28.0 & 63.5 \\
\hline
\end{tabular}

なお，焼鉱コンベヤ系統は，粉じん飛散防止の目的で ケーシング内をマイナスに維持するように，ファンでバ ッグ・フィルタに吸引ている。

\section{$3 \cdot 2$ 浸出}

浸出，洗浄，沪過は，す心゙て連続である。焼鉱はホッ

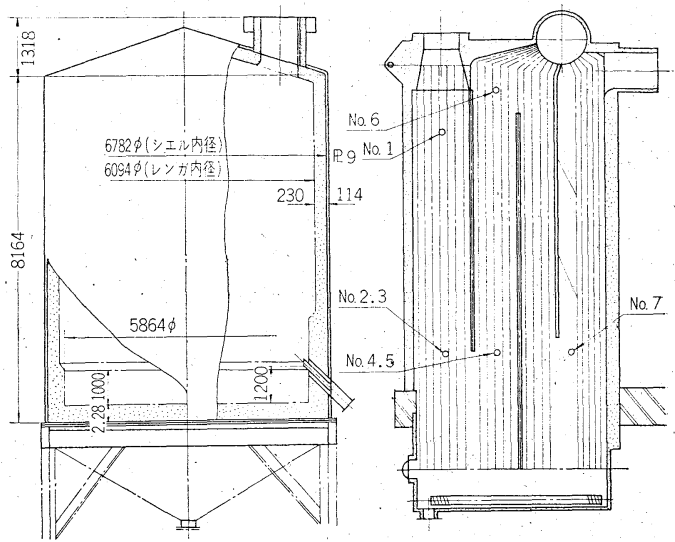

ドル式流動焙焼炉 400 型田熊排ガスボイラ

第 2 図焙焼炉，ボイラ側面図 
トカルサイン $\left(350 \sim 400^{\circ} \mathrm{C}\right)$ の状態で, 西鉛電解尾液中に クエンチングしたのち，100meshを分級点とするドラッ グベルト型分級機で分級し，末溶解の粗粒燒鉣をか上 げて，チューブミルで浸出しながら粉研する。乾式粉碳

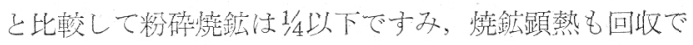
き，粉しんが全くたたないなどの利点がある。

湿式粉碎系統の浸出残渣粒度分布を第 9 表傜示す。

第 9 表 浸出残㴡粒度分布

\begin{tabular}{|c|c|c|c|c|c|}
\hline & $\begin{array}{c}\text { mesh } \\
+60 \\
\end{array}$ & +100 & +200 & -200 & 浸出率 \\
\hline 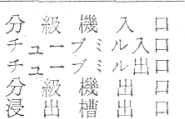 & $\begin{array}{c}2.3 \% \\
32.9 \\
1.1 \\
0 \\
0\end{array}$ & $\begin{array}{c}2.9 \% \\
12.8 \\
1.2 \\
0.9 \\
0.5\end{array}$ & $\begin{array}{l}32.2 \% \\
21.2 \\
13.2 \\
22.8 \\
7.3\end{array}$ & $\begin{array}{l}62.6 \% \\
66.9 \\
84.5 \\
76.3 \\
92.2\end{array}$ & $\begin{array}{l}75 \sim 77 \% \\
60 \sim 70 \\
70 \sim 75 \\
80 \sim 85 \\
92 \sim 94\end{array}$ \\
\hline
\end{tabular}

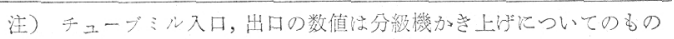

分級機オーバフローはさらに浸出槽に送り, 連続で浸 出, 第1 鉄酸化（マンガン鉱汇よる）在行なら。浸出系 統各所の $\mathrm{pH}$ 注第3図のよらであり, いわ河る連続逆浸 出である。

浸出時間柱 $8 \mathrm{hr}$, 浸出温度 $70 \sim 85^{\circ} \mathrm{C}$, 浸出率怯亜鉛 92 〜94\%，銅50〜60\%，鉄3〜4\%である。浸出パルプはシ ックナ4基で向流傾瀉洗浄老行ない, No. 1 シックナオー バフローは浄液工程へ送る。浸出残渣はアイムコ・ベル ト・フィルタで沪過したのちケーキとして, 銅製鍊自熔 炉に送っている。将来は, さらに浸出残渣中の遺利を回 收する予定である。残渣品位は第山表老参照されたい。

\section{$3 \cdot 3$ 浄液}

硫酸化烓燒当時は回分 3 段西碓酸浄液を行なつていた が，これも連続 4 段刺砒酸浄液とした。硫酸化焙誻によ るニッケル，コバルトの浸出率はかなり高く浸出液中の コバルト莀度は30 100 mg/lであつたが，酸化暗焼にな つてからは, $2 \mathrm{mg} /$ 前後である。

元銛銅品位の関係で浸出液銅濃度が常に $2 \sim 3 g / l$ と高 いのが特徵である。1段で洗浄ドロスおよざ雨鉛末を投 大して，液中残贸銅濃度50 $100 \mathrm{mg} / l$ まで脱銅すること により， 1 段後液の $\mathrm{pH}$ 走 2 段の亜砒酸浄液開始飞最適 のpH沉調節乙，脱コバル下反店を效果的江行ならとと もに，1 段，2段に扔けるカドミ損失を最少限度に止晾

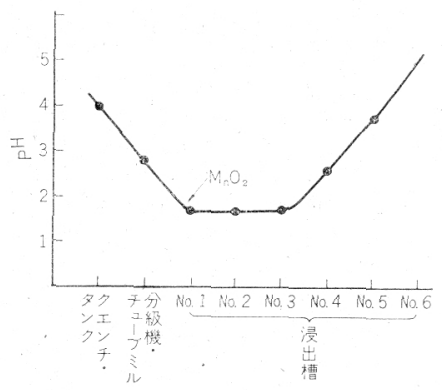

第3 図

浸出采統 各所の $\mathrm{pH}$

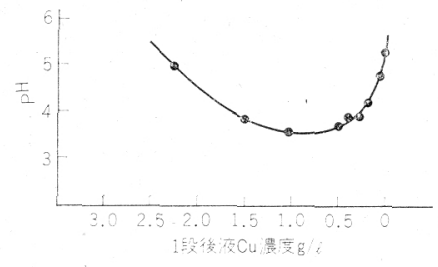

\section{第 4 図}

ている。第4図に当工場の 1 段後液の銅濃度と $\mathrm{pH}$ の関 係起示す。

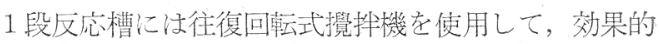
な攪拌比応の精度をあげている。2,3,4 段につい ても攪汼改良の余地がある。

浄液残渣沪過用フィルタプレスは, プレスライナにゴ ム製を使用し，手動締付けに代つて，油土締付けとして いる。第10表淮浄液操業デー夕を示す。

第10表 浄液操業条件之成䋶

笔気亚鉛 $1,540 \mathrm{t} /$ 月 液量 $16,400 \mathrm{~m}^{3} /$ 月

\begin{tabular}{|c|c|c|c|c|c|c|c|}
\hline & & 単位 & 原 液 & 1 段 & 2 段 & 3 段 & 4 段 \\
\hline 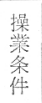 & 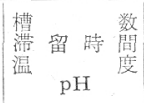 & ${ }_{{ }^{\circ} \mathrm{C}}$ & $\frac{}{60 \sim 65}$ & \begin{tabular}{|c|}
1 \\
80 \\
$60 \sim 65$ \\
5.0
\end{tabular} & $\begin{array}{c}3 \\
240 \\
80 \sim 85 \\
4.2\end{array}$ & $\begin{array}{c}2 \\
160 \\
70 \sim 75 \\
4.4\end{array}$ & $\begin{array}{c}1 \\
80 \\
60 \sim 65 \\
5.0\end{array}$ \\
\hline $\begin{array}{l}\text { 液 } \\
\text { 成 } \\
\text { 分 }\end{array}$ & $\begin{array}{l}\mathrm{Zn} \\
\mathrm{Cu} \\
\mathrm{Cd} \\
\mathrm{Fe} \\
\mathrm{Co}\end{array}$ & $\begin{array}{c}\mathrm{g} / l \\
\mathrm{mg} / \mathrm{l} \\
\mathrm{g} / \mathrm{l} \\
\mathrm{g} / \mathrm{l} \\
\mathrm{g} / \mathrm{l}\end{array}$ & $\begin{array}{r}143.0 \\
2,200 \\
355 \\
10 \\
1.8\end{array}$ & $\begin{array}{r}145.1 \\
70 \\
335 \\
10 \\
1.5\end{array}$ & $\begin{array}{r}145.6 \\
\operatorname{tr} \\
328 \\
10 \\
0.6\end{array}$ & $\begin{array}{r}146.3 \\
\operatorname{tr} \\
10 \\
10 \\
0.6\end{array}$ & $\begin{array}{r}146.8 \\
\operatorname{tr} \\
10 \\
0.6\end{array}$ \\
\hline $\begin{array}{l}\text { 残 } \\
\text { 咅 } \\
\text { 位 } \\
\end{array}$ & $\begin{array}{l}\mathrm{Zn} \\
\mathrm{Cu} \\
\mathrm{Cd}\end{array}$ & $\begin{array}{l}\% \\
\% \\
\%\end{array}$ & 二 & $\begin{array}{r}9.4 \\
61.5 \\
0.58\end{array}$ & $\begin{array}{r}15.7 \\
35.2 \\
3.5\end{array}$ & $\begin{array}{r}20.7 \\
\operatorname{tr} \\
39.8\end{array}$ & $\begin{array}{r}64.1 \\
\operatorname{tr} \\
3.4\end{array}$ \\
\hline $\begin{array}{l}\text { 残 } \\
\text { 垔垂 } \\
\text { 望 } \\
\text { 備 }\end{array}$ & 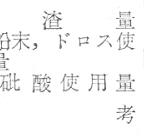 & $\begin{array}{l}\text { t/月 } \\
\text { t/月 } \\
\mathrm{kg} / \text { 月 }\end{array}$ & - & $\begin{array}{r}56.8 \\
42\end{array}$ & $\begin{array}{r}3.3 \\
9 \\
450 \\
40 \\
\text { 銅製鍊へ }\end{array}$ & 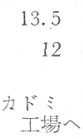 & $\begin{array}{r}4.6 \\
9 \\
3 \text { 段へ } \\
\text { 繰应し }\end{array}$ \\
\hline
\end{tabular}

\section{$3 \cdot 4$ 電解}

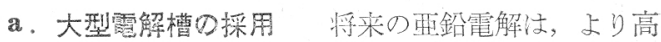
純度の電気丞鉛至製造すると同時に, 機械化, 長時間電解 などによつて，労力の節減をはかることが最も肝要であ る。電槽の大型化は，そのための必須条件であり，意欲 的に踏み切つた。通電以来, 非常に順調で当初心配した トラブルもなく安定した稆業を続けている。硫酸化暗焼

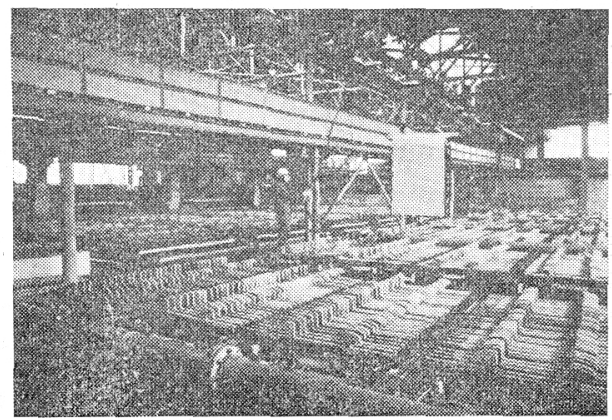

写真1 亜鉛電解工場 
第11表 大型槽，小型槽比較

\begin{tabular}{|c|c|c|c|c|c|}
\hline & 摘 & 要 & 単 位 & 大 & 型 \\
\hline & 析 & 出 垔 蛒 量 & $t /$ 月 & 1,228 & 346 \\
\hline 槽 & $\begin{array}{l}\text { 材 } \\
\text { 内 } \\
\text { 配 } \\
\text { 槽 }\end{array}$ & 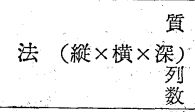 & $\mathrm{mm}$ & $\begin{array}{l}\text { 鉄板ゴムライニング } \\
2,750 \times 890 \times 1,425 \\
1 \times 6 \times 6, \quad 1 \times 6 \times 7 \\
78\end{array}$ & $\begin{array}{c}\text { 鉄板ゴムライニング・ } \\
\text { 鉄板塩ビ接着 } \\
2,000 \times 700 \times 1,200 \\
1 \times 3 \times 26 \\
78\end{array}$ \\
\hline $\begin{array}{l}\text { 陽 } \\
\text { 整 }\end{array}$ & $\begin{array}{l}\text { 形 } \\
\text { 材 } \\
\text { 寸 } \\
1\end{array}$ & $\begin{array}{l}\text { 状 } \\
\text { 質 } \\
\text { 法 }(\text { 縰 } \times \text { 横 } \times \text { 厚) } \\
\text { 槽当 } 引 \text { 枚数 } \\
\end{array}$ & $\mathrm{mm}$ & $\begin{array}{c}\text { 有孔平板 } \\
1 \% \mathrm{Ag} \text { 入 } \mathrm{Pb} \\
1,030 \times 745 \times 8 \\
31\end{array}$ & $\begin{array}{c}\text { 平 } \text { 板 } \\
1 \% \mathrm{Ag} \text { 年 } \mathrm{Pb} \\
745 \times 515 \times 8 \\
17 \\
\end{array}$ \\
\hline 陰 & $\begin{array}{l}\mathrm{Al} \\
\mathrm{d} \\
\mathrm{l}\end{array}$ & 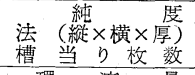 & $\begin{array}{c}\% \\
\mathrm{~mm}\end{array}$ & $\begin{array}{c}99.7 \\
1,150 \times 800 \times 5 \\
30 \\
\end{array}$ & $\begin{array}{c}99.7 \\
900 \times 580 \times 5 \\
16\end{array}$ \\
\hline 電 & $\begin{array}{l}\text { 循 } \\
\text { 液 }\end{array}$ & $\begin{array}{ll}\text { 環 液 量 } \\
\text { 温 } \\
\end{array}$ & $l / \min ^{\circ} \mathrm{C}$ 槽 & $\begin{array}{c}100 \\
35 \sim 38\end{array}$ & $\begin{array}{c}30 \\
35 \sim 38\end{array}$ \\
\hline 解 & $\begin{array}{l}\text { 給 } \\
\text { 液 } \\
\end{array}$ & $\begin{array}{c}\mathrm{Zn} \\
\mathrm{H}_{2} \mathrm{SO}_{4} \\
\end{array}$ & $\begin{array}{l}\mathrm{g} / \mathrm{l} \\
\mathrm{J}\end{array}$ & $\begin{array}{r}53.8 \\
139.5 \\
\end{array}$ & $\begin{array}{r}53.8 \\
139.5 \\
\end{array}$ \\
\hline 液 & 尾 & $\begin{array}{cc} & \mathrm{Zn} \\
& \mathrm{H}_{2} \mathrm{SO}_{4} \\
\text { 拔 } \quad \text { 出 } \\
\end{array}$ & $\begin{array}{c}\mathrm{g} / \mathrm{l} \\
1 / \\
\mathrm{m}^{3} / \mathrm{B}\end{array}$ & $\begin{array}{r}50.0 \\
145.2 \\
423 \\
\end{array}$ & $\begin{array}{r}50.5 \\
144.5 \\
120 \\
\end{array}$ \\
\hline $\begin{array}{l}\text { 添 } \\
\text { 加 } \\
\text { 阂 }\end{array}$ & 大 & 落 & $\underset{/ /}{\mathrm{kg} / \mathrm{t}-\mathrm{Zn}}$ & $\begin{array}{l}0.34 \\
0.14\end{array}$ & $\begin{array}{l}0.34 \\
0.14\end{array}$ \\
\hline $\begin{array}{l}\text { 電 } \\
\text { 解 } \\
\text { 条 } \\
\text { 件 } \\
\end{array}$ & $\begin{array}{l}\text { 陰 } \\
\text { 陽 } \\
\text { 槽 } \\
\text { 陰 } \\
\text { 電 } \\
\end{array}$ & 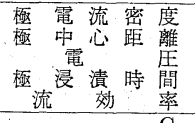 & $\begin{array}{c}\mathrm{A} / \mathrm{m}^{2} \\
\mathrm{~mm} \\
\mathrm{~V} \\
\mathrm{~h} \\
\% \\
\end{array}$ & $\begin{array}{r}425 \\
75 \\
3.45 \\
48 \\
4.2 . \\
\end{array}$ & $\begin{array}{r}430 \\
90 \\
3.60 \\
48 \\
90.0 \\
\end{array}$ \\
\hline 電電 & $\begin{array}{l}\mathrm{A} \\
\mathrm{D}\end{array}$ & $\because \quad \mathrm{C}$ & $\begin{array}{c}\mathrm{kWh} / \mathrm{t}-\mathrm{Zn} \\
/\end{array}$ & $\begin{array}{l}3,275 \\
3,144 \\
\end{array}$ & $\begin{array}{l}3,770 \\
3,280\end{array}$ \\
\hline $\begin{array}{l}\text { 整 } \\
\text { 流 } \\
\text { 器 }\end{array}$ & $\begin{array}{l}\text { 型 } \\
\text { 常 } \\
\text { 暧 } \\
\end{array}$ & $\begin{array}{ccc}\text { 式 } & \text { 台 } & \text { 数 } \\
\text { 用 } & \text { 電 } & \text { 流 } \\
& \text { 流 } & \text { 効 } \\
\end{array}$ & $\begin{array}{c}\mathrm{A} \\
\mathrm{\%} \\
\%\end{array}$ & $\begin{array}{c}\text { シリコン } 1 \text { 台 } \\
20,500 \\
300 \times 21,000 \\
96\end{array}$ & $\begin{array}{c}\text { 水銀 } 1 \text { 台 } \\
5,700 \\
750 \times 6,000 \\
87 \\
\end{array}$ \\
\hline 冷 & $\left|\begin{array}{l}\text { 中空 } \\
\text { 性冷 } \\
\text { 液塔 }\end{array}\right|$ & 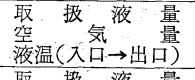 & $\begin{array}{c}\mathrm{m}^{3} / \mathrm{h} \\
\mathrm{m}^{3} / \mathrm{min} \\
{ }^{\circ} \mathrm{C} \\
\end{array}$ & $\begin{array}{c}23 \\
300 \\
60 \rightarrow 38\end{array}$ & $\begin{array}{r}23 \\
300 \\
60 \rightarrow 38 \\
\end{array}$ \\
\hline 却 & $\begin{array}{l}\text { 空 } \\
\text { 冷 } \\
\text { 塔 } \\
\end{array}$ & 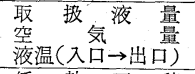 & $\begin{array}{c}\mathrm{m}^{3} / \mathrm{m} \text { in } \\
\quad / / \\
{ }^{\circ} \mathrm{C}\end{array}$ & $\begin{array}{r}8 \\
2,000 \\
38 \rightarrow 35.5 \\
\end{array}$ & $\begin{array}{l}\text { なし } \\
\text { "I } \\
\end{array}$ \\
\hline 置 & $\left|\begin{array}{cc}n \\
1 \\
\hdashline & 1 \\
1\end{array}\right|$ & $\begin{array}{l}\text { 低 熱 面 積 } \\
\text { 聚 拔 液 } \\
\text { 量 } \\
\text { 液温(入口 }(\text { 入出口) }\end{array}$ & $\begin{array}{c}\mathrm{m}^{2} \\
\mathrm{~m}^{3} / \mathrm{min} \\
{ }^{\prime} \mathrm{C}\end{array}$ & $\begin{array}{c}119 \\
1.6 \\
1.0 \\
38 \rightarrow 33 \\
\end{array}$ & $\begin{array}{r}119 \\
1.0 \\
0.8 \\
38 \rightarrow 34 \\
\end{array}$ \\
\hline $\begin{array}{l}\text { そ他 } \\
\text { の }\end{array}$ & 電 & 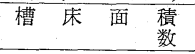 & $\begin{array}{c}\mathrm{m}^{2} / \mathrm{t}-\mathrm{Zn}_{\mathrm{n}} / \text { 月 } \\
\mathrm{I} / \mathrm{t}-\mathrm{Z}_{\mathrm{n}}\end{array}$ & $\begin{array}{l}0.49 \\
0.32 \\
\end{array}$ & $\begin{array}{l}1.17 \\
0.67\end{array}$ \\
\hline
\end{tabular}

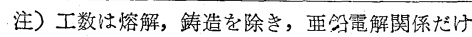

当時から使用している小型槽と併用しているので両者を 比較して第11表に示す。

b . 空冷塔の設置 亜鉛電解液の泠却はカーベイト クーラによる水泠方法を採つてきたが採鉱，選鉱，製鍊 各部門の拡張により，水源が不足してきたので空冷塔を 採用した。カーベイトクーラとの併用によつて盛夏にも 充分なる液冷却を行なつている。

第12表に亜鉛電解の熱收支を示す。

第12表 亜鉛電解の熱収支

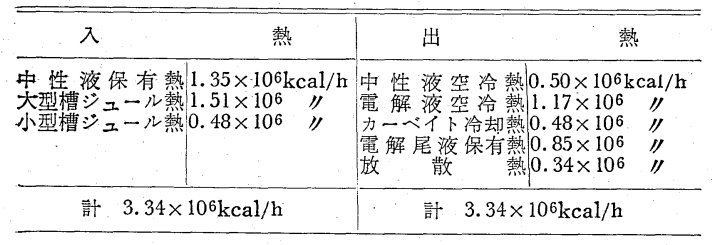

c. 諸設備の機械化 極板の引揚, 装入, 運搬はす ベて人力で行なつていたが横行, 走行のきくホイストク レーンによるクレーン作業とした。その他，陰極刺鉛は ぎ取り時の極板整列, はぎ取り後の積み重称, 陰極板研 摩, 熔解炉への陰極业鉛の投入などを機械化した。今後 さらに完全な機械化に努力したい。 d. 陰極西鉛の熔解 熔解炉 $150 \mathrm{~kW} シ ゙ ョ ッ ク ス 2 ~$ 基操業で, 直線 型鋳造機に連続注湯している。熔解用 電力は $107 \mathrm{kWh} / \mathrm{t}$-スラブで, ドロス生 成率は1.7 2.2\%である。ドロスは洗 浄脱塩素後浄液工程で使用している。

e.タイカスト合金の製造 昭和 42 年11月から ダイカスト合金 D Z - 1, D Z-2の製造を開始した。品質は極め て優良で需要家の好評を得ている。

\section{5 操業上とくに留意している点}

a. 液中塩素濃度当工場の条件 で液中塩素濃度と, 電気亜鉛中鉛品 位には，第 5 図のような関係があるの で，実操業では液中塩素濃度の上限を $50 \mathrm{mg} /$ ししている。これに関連して, 浄液工程に使用するドロスは脱塩素洗 浄を行ない, 系内に塩素が混入しない よう留意している。

b. アンチモンについて 銅転炉 煙灰浸出液を亜鉛回収の目的で系内に 入れている。この液中には $50 \sim 100 \mathrm{mg}$ /lのアンチモンが含まれているので, 系内に直接入れる液量を制限し; 混合 後の液中アンチモン濃度を $3 \mathrm{mg} / l$ まで とし, 余つた液は焙焼炉冷却水として 使用し，炉を通すことによつて，アン チモンの形態を溶解度の低いものに变えて液中のアンチ モン濃度を調節している。

\section{$3 \cdot 6$ 計測, 制御}

焙焼炉の自動温度調節, ボイラ液面圧力制御, 浸出工 程の $\mathrm{pH}$ 測定と液面制御, 浄液工程の $\mathrm{pH}$ と液面の制御, 電解液の酸濃度測定などを行なつている。さらに工程管 理上必要な計測, 自動制御を強化するとともに極力少数 の検出端によつて管理できるように工夫したい。

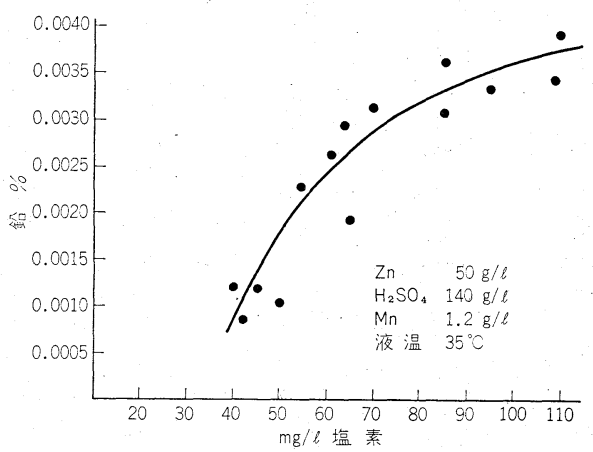

第 5 図 電解液中塩素濃度と電気亚鉛中鉛(\%) 


\section{4. 結言}

硫酸化焙焼から酸化焙焼への転換に際して，いままで の経験を生かして工程の連続化, 合理化を行なつた。
黒鉱から産出する重鉛精鉱の処理に関する主要な問題 点は, ほとんど解決した。今後は遺利の回収を推し進め るとともに, 将来に備えて, 操業技術の練摩, 工程の機 械化，人員の合理化に一層の努力を傾けたい。

\section{秋田製煉所10年の回顧}

\section{Zinc Smelting at Akita Refinery}

正会員森 山栄 夫* Eifu MORIYAMA

\section{1. 緒 言}

三菱金属鉱業株式会社秋田製煉所は，当初，社内鉱で ある生野および明延両鉣山の亜鉛精鉱の処理を主目的と して建設された。

その後, 日本の経済界は拡大の一途をたどり, 非鉄金 属業界も「貿易の自由化」にさらされることとなり，こ れが「技術革新」の原動力となつた。その波は，当所が 鉱山付属製錬所というせまい殼にとどまることを許さず 買鉱製錬所への脱皮をらながすこととなつた。

当所は，製錬方式において

a. 設備の大型化と操業の連続化

b. 諸設備の機械化と合理化

c . 遺利回収の徹底化

という 3 本の柱を基本的方針として打出し，この10年間 対処してきた。さらに，製鍊方式のみでなく湿式亜鉛製 錬の，もつとも特徵とする高純度覀鉛の利用面にも視野 を広げ，MAK 2 種等のダイカスト用合金製造を開始し た。

\section{2. 操 業}

過去 10 カ年間の当所の生産量推移が第 1 図に示してあ

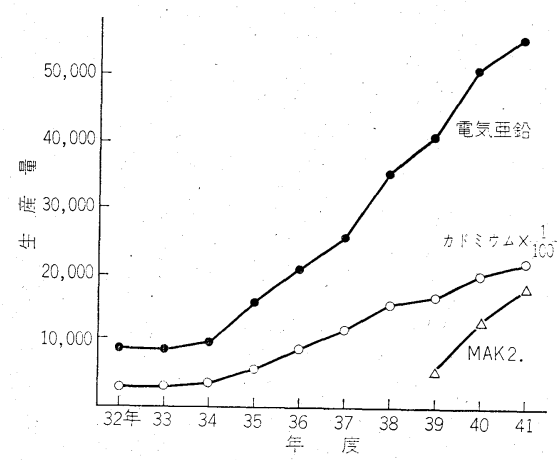

第1図 過去10力年間の生産量の推移

* 三䔖金属鉱業株式会社秋田製棟所副長
る。また，フローシートは第2図のようである。

処理量および生産量については第1 表のように, '過去 10 カ年間に約 1.7 倍の人員によつて約 6.5 倍の生産量を碓 保することとなった。

現設備の主要機器を第 2 表に示した。これは, 設備桩

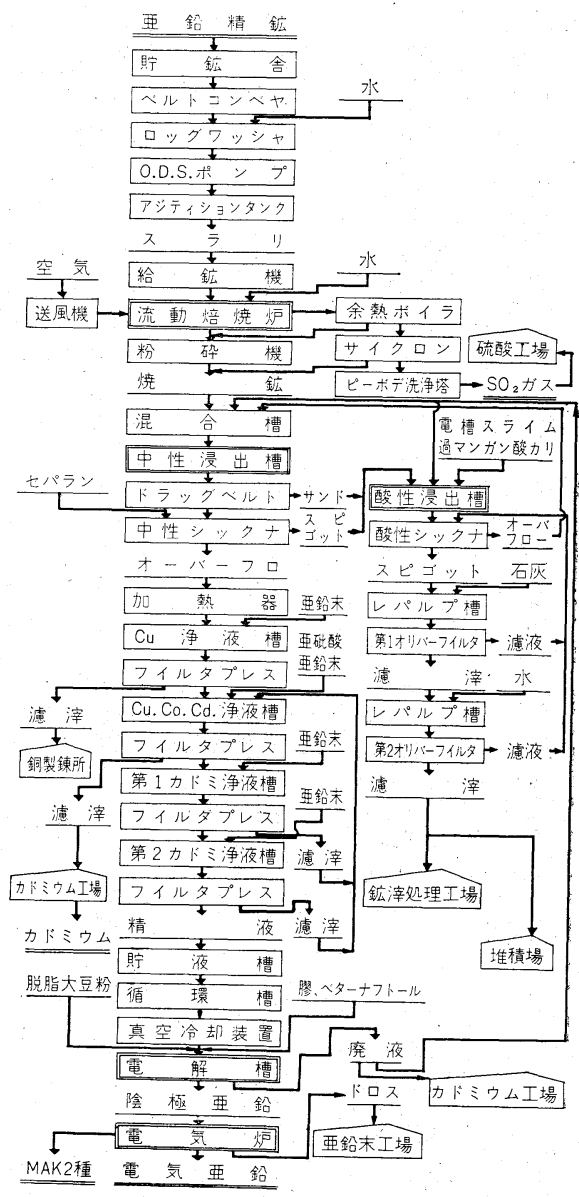

第2図フローシート 